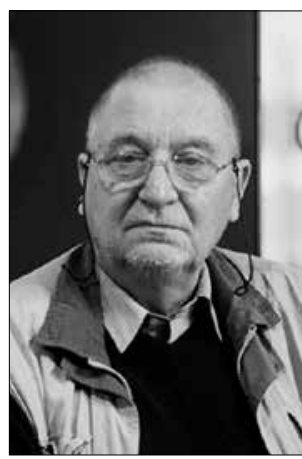

https://doi.org/10.24101/logos.2017.49

Received 23032017

\title{
CHRISTIAN GIORDANO
}

University of Fribourg, Switzerland

Fribourg universitetas, Šveicarija

\section{WHAT IS A MEDITERRANEAN AGRO-TOWN? ON THE SENSE AND NONSENSE OF ANTHROPOLOGICAL DICHOTOMIES}

Koks yra Viduržemio jūros regiono agro-miestas? Apie antropologijos dichotomijų prasmę ir absurdiškumą

\section{SANTRAUKA}

Antropologijos ir sociologijos teorijos dažnai pagristos tikslingomis skirtimis arba, kitaip tariant, dichotomijomis. Prieš porą metų Crisas Jenksas išleido knygą Sociologiniu dichotomiju šerdis, kurioje kritiškai pateikè pagrindinius jų tipus. Šis tekstas rodo, kad geriau ar blogiau, paskutiniaisiais 150 metų dichotomijos buvo fundamentalus sociologinės ir antropologinės minties aspektas. Straipsnyje iliustruojama, kad dichotomijos, vengiant esencialumo rizikos, t. y. statinių realybės konstruktų, yra naudingos, o gal nepakeičiamos atliekant socialinę analizę ir kuriant teorines sampratas socialiniuose ir kultūriniuose moksluose.

\section{SUMMARY}

Anthropological and sociological theories are often based on purpose-made dichotomies. A few years ago, Chris Jenks even published an entire book titled Core Sociological Dichotomies with a critical presentation of the principal types. This text aptly argued that, for better or for worse, for the past 150 years dichotomies have been a fundamental aspect of sociological and anthropological thought. This article iillustrates how dichotomies, aside from the risk of essentializing, i.e. of creating static constructs of reality, are useful if not indispensable for a social analysis and for the creation of theoretical conceptions in social and cultural sciences.

\section{INTRODUCTION: THE ROLE OF DICHOTOMIES IN SOCIAL SCIENCES}

Dichotomous thought, by which one tive and mutually exclusive ones, is as concept is divided into two jointly exhausancient as philosophy. Yet, dichotomous 
classifications are also undeniably embedded in everyday thought and knowledge, where they prove to be significant instruments of intuitive knowledge.

Given their extensive employment, dichotomies not surprisingly became a crucial instrument of theoretical conceptualizations in social sciences as well, especially from the second half of the $19^{\text {th }}$ century, i.e. when social sciences started to developed more systematically.

We need only mention two of the founding fathers of social sciences, Emile Durkheim and Ferdinand Tönnies, who conceived two of the most renowned dichotomies to this day.

Emile Durkheim famously proposed distinguishing between two fundamental and opposite forms of solidarity, i.e. organic and mechanical.

Durkheim points up that mechanical solidarity emerges and develops in situations of proximity, where the various actors maintain strongly personalised relationships and live in relatively small communities. This form of solidarity springs from an affinity of roles and behaviours, hence the division of labour is scarcely developed (Durkheim 1893). Accordingly, mechanical solidarity is based on similarity and is generally prevalent in small groups such as family, kin, village and tribe. These small collectivities, where highly personalised relationships are prevalent, are far more important than the single individual. Ultimately, according to Durkheim, mechanical solidarity is a social characteristic of archaic, primitive, backward, segmentary and traditional societies.

Durkheim's representation of mechanical solidarity, however, bears a striking resemblance with societies under colonial regimes or possibly the France profonde peasant communities of his times.

Organic solidarity emerges in societies characterised by marked social differentiation, thus with a highly differentiated system of social division of labour, which generates a considerable complexity of social roles and positions. Accordingly, societies based on organic solidarity have a high degree of specialisation, which may be regarded as a true guarantee of social cohesion since everyone is dependent on everyone else's labour. Organic solidarity, therefore, is rooted in the certainty of reciprocal dependence between people who have a specific function or exercise an activity within society. Consequently, unlike societies based on mechanical solidarity, these societies lack a strong collective consciousness, but have an individual awareness that the division of labour safeguards the existence of their members. This promotes an allegiance not as much to persons, but rather to public institutions along with the laws, norms, rules and customs of the collectivity. The formal legal system based on the law of restitution and contractual practices thus finds its legitimacy. Finally, given their specific social structure, these are modern societies with a great number of members and are characterised by considerable social complexity.

In the pair mechanical solidarity/organic solidarity formulated by Durkheim, an implicit value judgment, perhaps involuntary, spontaneous and possibly unconscious, comes to the fore. Essentially, societies based on organic solidarity are deemed more advanced, thus also more modern, since even the subtitle of 
Durkheim's book in a so-to-speak spontaneous manner mentions the concept of sociétés supérieures. In Durkheim's book, societies characterised by mechanical solidarity are undeniably survivals, in the words of Edward B. Tylor (Tylor 1871), i.e. a residual category or, better yet, a relic of the past. Thus, mechanical solidarity is a phenomenon heading towards extinction, whereas organic solidarity - implying modernity - is the present and above all represents the future. Even an insightful observer such as Durkheim lapses into a number of clichés typical of a specific evolutionism of his times.

On the other hand, Ferdinand Tönnies points up the substantial difference between Gemeinschaft and Gesellschaft (Tönnies, 1912). He defines Gemeinschaft as a specific form of social organization based on a strong feeling of belonging to the community's activities and on the spontaneous participation of its members in its activities. Gemeinschaft, therefore, is typical of societies deemed primitive as well as rural. In the Gesellschaft, instead, individualism, subjectivity and contractualism are predominant. The latter, therefore, emerges as a permanently shifting, individualist type of society in which impersonal relations are predominant. Clearly, Tönnies is referring to modern society.

In the wake of these two initial dichotomies, other authors proposed further and often analogous ones, though with different overtones, among which we will mention the ones between nature and culture, continuity and change, local and global, tradition and modernity, race and ethnicity and, above all, the one between urban and rural (Jenks, 1998).
All these dichotomies are effective, yet also misleading. In fact, the various concepts included in the dichotomies should not be understood as empirically observable reality. Mechanical solidarity or Durkheim's mechanical solidarity or Tönnies' Gemeinschaft cannot be verified empirically. Nevertheless, they prove to be extremely useful to create the necessary theoretical conceptualization at an analytical level. As we shall see, they can be very effective in the in-depth study of specific complex and hybrid social realities such as Mediterranean agro-towns.

In social sciences, and in anthropology in particular, the terms constituting the dichotomies are Weberian ideal types (Weber, 1956). Therefore, they are theoretical and methodological utopias artificially created by sociologists and anthropologists to unscramble and classify social complexity. They are intellectual constructs, which may be regarded as conceptual exaggerations. Dichotomies, however, allow discovering the essential traits of various social realities. These diametrically opposite concepts, therefore, are indispensable in a comparative analysis of an interpretive nature between different forms of society.

The empirically observable reality between these two extremes falls along a continuum in which countless variations may be observed. Between two dichotomous ideal types, therefore, there is always a grey area wherein lies empirical reality. Yet, as we shall see, there are also everyday and likewise ideal typical dichotomies created by the actors themselves, which thus pertain to local knowledge (Geertz 1980). 


\section{WHAT IS A MEDITERRANEAN AGRO-TOWN? IN SEARCH OF A DEFINITION}

Anyone travelling from Europe's regions north of the Alps to the continent's southern reaches or more in general the Mediterranean area, i.e. Portugal, Spain, Italy, Greece, Turkey, the Middle East, the Maghreb etc., is invariably amazed by the landscape.

Along with vast and nearly deserted or scarcely populated agricultural areas there are urban agglomerations with far more inhabitants than those found in Alpine villages or in other rural areas of central, eastern and northern Europe. A North European, in fact, envisions a rural environment as consisting chiefly in small urban agglomerations surrounded by small or at times mediumsized farmsteads applying intensive farming methods.

The rather complex and quasi-elusive term agro-town was coined by re- searchers from North Central Europe, thus highlighting their amazement since they are not familiar with this type of reality. In line with their perception, an agro-town may be defined as an urban agglomeration in a rural setting with a number of inhabitants in excess of several thousands where most of the population works in agriculture whereas commercial or industrial activities are rather rare. The observation of this apparent paradox, i.e. a rural urbanity, is precisely what kindled the researchers' interest in these human settlements. After all, Mediterranean agro-towns lie halfway in one of the most well known dichotomies, i.e. the one between rural and urban. In the next sections we will discuss the most significant social and cultural characteristics of Mediterranean agro-towns.

\section{THE DICHOTOMOUS REPRESENTATION OF SOCIETY. CONSTRUCTION AND REPRESENTATION OF SOCIAL INEQUALITIES IN MEDITERRANEAN AGRO-TOWNS}

Polish sociologist Stanisław Ossowski (1962) must be given credit for pointing up that social inequalities are not solely the outcome of social sciences' theoretical reflection. The actors themselves perceive them and build hierarchical representations accordingly. These representations of a vertical order, by which "some stand above (or below) the others", are not only a theoretical speculation, but are also produced by the society's members themselves (Ossowski, 1962: 33 ff.).
The image of a stratified society emerges also in the collective representations of Mediterranean agro-town inhabitants. Furthermore, Mediterranean agrotowns are characterized by a specific culture of social inequality, which is why some authors have rightly spoken of a hierarchical ontology (Mühlmann, Llaryora, 1973: 85). Hierarchical ontology may be regarded as a value system's generalized principle, i.e. a way of thinking and acting that ultimately classifies people and property along a high to low ranking. 
Moreover, the lower classes view this state of affairs as an unpleasant and possibly odious reality but an inevitable one. We should also add that these classes usually view the positions of power, political power in particular, as disagreeable and unfair, while power itself is often defined as punitive (Belluardo, 1977: 85). It may seem surprising that these classes take no steps to change this situation, yet for them the hierarchical structure, thus also the positions of power, are practically unchangeable, though essentially negative (Belluardo, 1977: 95). Thus, the hierarchical ontology incorporates the conviction that the social difference between people, strata and social classes is a so-to-speak natural phenomenon and that the social hierarchy shifts while reproducing itself, but is ultimately persistent.

This certainty about continuity despite changes in the social order evidently discourages the inhabitants' participation in movements that promote the emancipation of the disadvantaged classes and their participation in the democratic system. These emancipation strategies are regarded as noble yet illusory and alien, and are often viewed as calculated, well-advertised overtures of politicians seeking to legitimize or bolster their chances of being (re)elected.

Social sciences build complex systems of stratification, but agro-town inhabitants, like many other average citizens, develop simpler, straightforward, bipolar-like conceptions comprising only two hierarchically overlapping groups.

Three types of dichotomous stratification can be observed in the perceptions of Mediterranean agro-town inhabitants:
1) Those for whom one works and those who work

2) The rich and the poor

3) The powerful and the powerless, i.e. those in command and those who obey.

\section{Those for whom one works and those who work}

The first of these dichotomies is widespread in many societies (Ossowski, 1962), particularly so in agrarian societies. Unsurprisingly, therefore, it can be observed in Mediterranean agro-towns. In accordance with this dichotomy's leitmotiv, labour, i.e. agricultural thus manual labour especially, is central to this hierarchical social distinction. Most importantly, in the representations of Mediterranean agro-town inhabitants this physical activity is viewed as necessary yet also demeaning and undignified for human beings (Tentori, 1971, vol. 3: 110).

This negative attitude towards manual labour is often thought to be widespread essentially among the higher classes, such as the galantuomini in southern Italy and the señoritos in southern Spain's Andalusia and La Mancha who rather surprisingly, though, seem to lack a strong bond with the land. Italian sociologist Gasparini noted that in southern Italy, unlike northern Italy, those who till the land lack any strong bond with the land and indeed in many cases display an aversion to agriculture-related manual labour (Gasparini, 1978: 280-281).

Yet, having a job, however unpleasant, is better than having none. Subordinate classes dread unemployment as it puts them at risk of an even worse fate, 
i.e. being out of work and a beggar. The latter is on the bottom rung of the Mediterranean agro-towns' social ladder (Pitt-Rivers, 1977: 103).

This negative image of those who till the land, thus perform manual labour, means that the positive persons of reference in Sicilian agro-towns are those who belong to the so-called classes paresseuses who can afford to not be engaged in any profession, thus to not work and consequently pursue the ideal of a dignified leisure. For example, up to the land reform, the positive group of reference in Italy's south included the absentee aristocrats, who resided in particular in Palermo or Naples, and the so-called galantuomini or civili, i.e. midsize landowners, who could not afford to live in these two capitals and stayed in the agro-towns instead.

The concept of dignified leisure implies that people with means should avoid any intellectual or manual labour and should live in an urban environment. This ideal of life is a form of moral and material leisure in which good practices of behaviour, typical of large cities, predominate. Country life and agricultural manual labour are equally dreaded by the higher nobility and especially by the less affluent galantuomini in southern Italy and the various señoritos in Andalusia and La Mancha. Contrary to what might be expected, farm workers share these views; therefore, their hardly attainable ideal is to own a patch of land that would allow them to lead a life of dignified leisure (Mosca, 1980: 63).

This negative attitude towards anything agricultural is in contrast with certain ideal visions of agricultural rural life that, instead, are very widespread in Europe's northern and eastern regions as well as in social research. Consequently, the underlying social logic of dignified leisure is difficult to grasp for anthropologists since they actually view this lifestyle as something alien, if not deplorable.

In the past, the social difference between those who perform manual work and those who can afford a life of dignified leisure was noticeable even in the different dress codes. In fact, Sicilian aristocrats and galantuomini, i.e. urban dwellers, wore hats, thus were known as cappeddi (from cappello, hat), whereas peasants, i.e. country people working in the fields, wore caps, thus were nicknamed birritta (from berretto, cap).

In agro-towns, this clear-cut differentiation between country and urban dwellers is symptomatic of the urban ideal typical of many Mediterranean societies, which to this day is neither an anachronism nor a tradition typical of archaic societies. Nowadays, an alternative breakaway from the dire fate of working the land or having to live in a rural environment is an escape towards the service industry. Under this aspect, a possible employment in the tertiary sector, even more so in the public sector, plays a crucial role. Opportunities available in the so-called assisted economy, and above all the State's generous allocation of pensions and subsidies along with the public administration's expansion, also offer the chance to reach the coveted goal of being perceived as an urban dweller. In Mediterranean societies, the endeavour is an important strategy in the politics of reputation (Bailey, 1971: 1). 
In conclusion of this section on the dichotomous conception of those for whom one works and those who work, Mediterranean agro-towns can be said to be a materialization of their entire population's urban aspirations, thus dimming the imagined, and dichotomously experienced, social structure separating urban and rural population (Blok, Driessen, 1984: 115).

\section{The rich and the poor}

This dichotomy may seem predictable at first since it occurs in countless societies; however, in Mediterranean societies it has a distinctive characteristic. According to the representations of Mediterranean agro-town inhabitants, in fact, the rich don't need to work, thus whoever doesn't work is rich.

This is not just a play on words since it mirrors the collective certainty that wealth is a prerequisite to attain the urban life ideal linked to a high social status. In Mediterranean agro-towns, wealth is one of the basic criteria to determine social rank. Paradoxically, a person's wealth is more important than an aristocratic lineage. Indeed, in Sicilian agro-towns there's the saying that without wealth even health may be unwholesome (Pitrè, 1978, vol. 3: 78).

Clearly, wealth is always viewed in contrast with poverty. Whereas the rich are associated with positive qualities such as successful, powerful, distinguished, cultured, intelligent etc., the poor are by definition despicable, ignorant, stupid, insolent (Pitrè 1978, vol. 3: 251 ff.). Wealth is equated to a superior intellect, whereas poverty is linked to an intellectual deficit. Given this value system, in Mediterranean agro-town societies property is the yardstick to measure both wealth and poverty. This dichotomy can be reformulated as the polarity between those who own and those who do not own. Thus, the social standing of Mediterranean agro-town inhabitants is determined by ownership differences and not by the power to purchase property and services.

Amongst the wealthy, as a privileged group, there are far more persons who live off private income, mainly from landed property, than entrepreneurs. Thus, in terms of the recognition of belonging to a specific social rank, ownership (of land, a house or livestock) is far more important than having monetary resources in a bank. Thus, there is an almost mystical sentiment towards landed property.

In line with this mystical conception of property, everyone doggedly strives to obtain and monopolize it by whatever means possible. In Sicily and Italy's south the term roba defines this obsession of owning real estate. Yet, the concept of roba also includes the idea of the rapacity of the person aiming to own real estate by any means. Roba is not only purchased, but also and above all greedily amassed. Greed and rapacity are certainly not viewed as positive qualities in southern Italy, but in the specific context of the acquisition of roba, southern Italy's agro-town society tends to regard them as two rather normal characteristics, if not indeed rational or desirable ones.

The glorification of the roba, especially in the past, was typical of the mind-set of those who had managed to rise above their peasant poverty, thus of 
that rapacious middle class aiming to lay hands on as much land as possible. In fact, the aristocracy regarded the management of their lands as well as increasing their estate's extension as undignified precisely because of their traditional absenteeism. The chief concern of the landless peasant class was its day-to-day survival, thus they had no time left to worry about the roba, which at best was an impossible goal. Consequently, the quasi-mystical veneration of the roba was typical of the middle classes comprising galantuomini and señoritos.

In Sicily this glorification of the roba also pertains to Mafia culture and practices. Nowadays, however, the Mafia's appetite for land has turned into a hunger for buildings in large cities such as Palermo and Catania, which characterizes the real estate speculation in this crucial sector for the island's economy. Major amounts of money can be amassed through these practices.

The conception of the roba amongst the galantuomini and señoritos runs parallel to the land hunger of the social strata that works in the fields, i.e. the aspiration, often unattainable, to own a small plot of land to better one's social standing. Given the intrinsic difficulties of realizing this dream, many of the Mediterranean agro-towns' farm workers and field hands migrated to their country's industrialized areas and subsequently abroad, especially to northern Europe.

Finally, it should be noted that the relation between the entire population of Mediterranean agro-towns, i.e. absentee aristocrats, galantuomini, señoritos and finally peasants, and the land is not negative but functional. Quite surprisingly, and contrary to some romantic peasants especially have no strong bond with the land, but rather view it as an object or, better yet, an impersonal asset, which is imperative for the social advancement that would fulfil their ideal of becoming city people and no longer country folk.

The powerful and the powerless: Those in command and those who obey

We will now tackle the crucial dimension of power as the generating and structuring principle of dichotomous hierarchies. The theme of power and its institutionalization, i.e. the various forms and structures of authority, play a major role in the historical experiences handed down to the Mediterranean societies' present. Undeniably, therefore, the current collective consciousness, with its representations and social constructions, is acutely aware of social differences stemming from practices of power and authority. Accordingly, the pervading certainty in these societies is that by definition some are powerful and force their will even on those who dispute it, whereas some are powerless and obey and carry out whatever they are ordered to do. Thus society is divided into rulers and ruled. For the actors of Mediterranean agro-towns, society is characterized by a dichotomous structure as in the previously analysed cases. However, the two previously analysed dichotomies are also strictly correlated. In fact, those with power and authority are the city people, the wealthy and the owners, whereas those who have neither are the country folk, the poor and the landless. Galan- 
tuomini and señoritos belong to the powerful group whereas ordinary farm workers are powerless, thus are forced to obey.

Moreover, the generalized opinion is that the actions of whoever governs are not aimed at ensuring the common good but rather their personal advantage. Under this aspect, in Mediterranean societies a politician is never regarded as a statesman honestly managing public affairs, whereas the bureaucrat will take advantage of his role as a manager of state finances to further his own interests or to favour relatives and friends. These individuals are not guided by ethic principles or sense of responsibility but solely by personal interest. Consequently, politics is regarded as something dirty.

As Sicilian writer Leonardo Sciascia rightly pointed up, governing, policymaking or managing the common good are viewed as something dirty, worse still as a mortal sin or a process of putrefaction (Sciascia, 1976). Given this remark by perhaps the keenest observer of his native island's practices of power, we would add that as a rule in Mediterranean societies the administration is often, and rightly so, viewed as maladministration (Giordano, Greverus, 1986: 360). According to anthropologist Jeremy Boissevain, Mediterranean agro-town politicians cannot be honourable if they want to be successful via their manipulations (Boissevain, 1974). Thus, an elected official is intrinsically a petty politician who forwards his career thanks to his manipulations to the detriment of the State and of its citizens.

The ambivalent attitude of those who obey towards those who govern brings to the fore a specific bipolar antagonism of the powerless towards the powerful. In fact, in the first two dichotomies, i.e. between those for whom one works and those who work and between the rich and the poor, the people on the higher rungs of the social ladder represent the positive reference group, whereas in the third dichotomy, between those in command and those who obey, this assessment is reversed. Indeed, the dominators, i.e. politicians and bureaucrats, have a terrible repute amongst the dominated, i.e. those who must obey. This could lead to the impression that the relationship between the powerful and the powerless is characterized by a conflict between two social classes; a faulty impression because, despite some sporadic forms of social rebellism, the relationship between powerful and powerless is more transactional than conflicting. Thus, envisaging a possible Marxian class struggle would be a misconception. Rather, relationships between those who obey and those in command are clientelistic. As such, relations between individuals from the two groups are based on the patron/client relationship. The important point here is that there is a constant exchange of informal favours and counter-favours between the actors who have power, authority and influence, and those who lack these political or bureaucratic resources. Consequently, clientelism is not only a basic element of the Mediterranean agrotown's social structure, but also a collective attitude superimposed on the objective class relations (Li Causi 1979: 49).

My fieldwork experiences in the Mediterranean area cooperatives corroborate these findings (Giordano, Hettlage 1979). These theoretically horizontal 
associations, in fact, quickly turn into vertical organizations steeped in clientelism. Actually, we could call them forms of all-pervasive clientelism, literally omnipresent in the Mediterranean area's voluntary associations and civil society organizations.

Furthermore, members of these associations do not view this social relations structure as anomalous or indeed pathological. For them, a leader is someone who, beyond the limited agro-town life, has important connections that could be useful: therefore, a person with power and authority whom one can resort to in case of need. Any favours received, how- ever, must be adequately reciprocated with clientelistic-like counter-favours. One of my interviews reveals that the ideal president of a cooperative should be competent, communicative and knowledgeable, and well connected at a regional and national level.

Among Mediterranean agro-town inhabitants and especially among the lower classes we can observe an extreme mistrust in public institutions and politics, thus also in those who in some shape or form govern and have power and authority. Consequently, they may rightly be characterized as public mistrust societies (Giordano 2012: 119 ff.).

\section{MEDITERRANEAN AGRO-TOWNS AS PUBLIC MISTRUST SOCIETIES}

In line with the above points on the relationship between those who govern and those who obey, Mediterranean agro-town inhabitants envisage a clearcut separation between public and private sphere and the supremacy of the former on the latter. The consequent evaluation of these societies' members is categorical: the private sector is regarded as the social space of security, trustworthiness and solidarity, while the public sector is perceived as a dangerous foreign body. Thus it follows that everyone will try to privatize the public sector and exploit it to their own advantage. By this social logic, building personalized relationships and networks is a necessity since they are the only ones that can ensure a certain quantum of trust.

Clearly, family and kin form the core of these relationships and networks. In fact, these two basic social institutions are the only ones that can guarantee $\mathrm{co}^{-}$ operation without a hidden agenda. However, we should avoid Edward C. Banfield and Robert Putnam's mistake of thinking that Mediterranean agro-towns are solely an assemblage of families and that other forms of sociability are either lacking or scarcely developed (Banfield 1958, Putnam, 1993; Tullio Altan, 1986). A closer look at these societies reveals that their members believe in the need to extend their relationships of solidarity beyond family and kinship ties.

In Mediterranean agro-towns, when we look beyond family and kinship structures, we ought to consider above all the importance of informal interaction networks, which could be defined as a system of dyadic relationships.

Among the several types of dyadic relationships used in the agro-towns to make the public sphere more trustworthy, one of the most important ones is ritual or symbolic kinship, i.e., godparenthood 
(It.: comparaggio Sp.: compadrazgo). The close net of kinship relationships of a symbolic nature involves an action strategy aimed at establishing a long-term alliance between various individuals or groups of blood-relations and kinsmen sharing a fairly equivalent social status. In Mediterranean agro-towns, another far more common chance to extend protection and solidarity structures is to establish dyadic relationships of symbolic kinship with people with a higher status and social prestige and/or with better political and economic opportunities than one's own. In these cases the poor, the underling, and the powerless tend to choose their godfathers among rich and powerful people who can provide the necessary assistance to secure personal interests within the public sphere (Pitt-Rivers, 1977: 54; Zimmermann, 1982: 76 ff.; Vuidaskis 1977, 91 ff.). Within the framework of this analysis we need to underscore that ties of symbolic kinship always imply reciprocal rights and duties that guarantee the informal exchange of favours and counterfavours between socially superior and socially inferior actors.

The second type of interpersonal relationship comprises the ties of friendship. In general the social institution of friendship is based upon symmetrical extra-kinship and extra-family relationships. Friendship ties usually develop among people belonging to the same class or equivalent/analogous social strata (Mühlmann, Llaryora, 1968: 8; Schiffauer, 1983: 124).

However, the notion of symmetry leads to another feature of friendship relations that is quite prevalent in Mediter- ranean agro-towns; namely, the transactional aspect of these dyadic relationships, which, as a rule, involve informal instrumental interactions (Boissevain, 1974; Wolf, 1966: 10 ff.). In public mistrust societies, the instrumental aspect is intrinsic to friendship and the exchange of material favours is openly performed. These transactions among friends are not stigmatized at all, though the affection aspect is not missing and coexists smoothly with other types of favours and counter-favours in these societies as well.

In practical terms, we can add that in public mistrust societies an individual who needs to speedily solve a problem with the civil law or wants to obtain a permit, a pension, or a license that depend upon the decision of a remote and unfamiliar office in the capital, will not apply to the relevant authorities in person but will mobilize a close friend. The latter in turn will get in touch with acquaintances occupying important positions in the magistracy or civil service who will help deal with the case. These instrumental relationships based on transactionality, thus on reciprocity, entail equivalent counterfavours - in our case, the mediation of acquaintances with high-ranking people.

The term friend, according to the word's instrumental and transactional meaning, and the term acquaintance are often nearly synonymous. This was true in the long period of realized socialism for example and can still be found in postsocialist transition societies. Consequently, acquaintances imply the existence of a network of dyadic and polyadic social relationships based on transactional reciprocity, which is put to use to obtain what are regarded as vitally important 
personal favours at the expense of the common good and public resources (Ledeneva, 1998: 37). Being an economy of favours, acquaintances, especially during the socialist era, was a practically universal system of informal network that enabled these coalitions of friends and acquaintances (at times just temporary) to appropriate material-like common goods as well as symbolic-like State privileges via highly-personalized channels.

Finally, we ought to highlight that money plays a secondary role in the mentioned three types of relations and coalitions. Therefore, this phenomenon must be fully distinguished from corruption, which instead is characterized precisely by its monetary aspect.

Finally, we need to mention the vast diffusion of clientelistic practices. The relationship between patron and client can be defined as an interpersonal and dyadic tie regulated by rights and duties usually informally defined. However, the tie between patron and client gives rise to an asymmetrical type of reciprocal dependence, since the client depends more on the patron than vice versa (Mühlmann and Llaryora, 1968: 3). The relationship between patron and client implies a marked social, political and economic inequality between the people involved.

The institution of patronage permeates all organizations and associations linked to wielding and controlling power. Consequently, with its implicit strategy of personalizing social relationships, the clientele system becomes the so-tosay backbone of the management of the common good, which is privatized via extensive and multi-fold vertical links.
By now, each Mediterranean agrotown is embedded in a modern bureaucratic order. Thus, there is a more or less centralized territorial State based on a standardized administration, (in principle) impartial and hierarchically structured. Transactions between patrons and clients, in the shape of asymmetrical favours and counter-favours, are usually carried out in contexts where the administration of the common good is well known to be crucial. Exemplifying, relationships between representatives of the State's power (i.e. politicians and state officials) as well as managers of civil society organizations (NGO, co-operative association, or trade union directors, for example) on the one hand, and common citizens on the other, do not comply with the principles of objectivity of common interest decreed by the abstract models of bureaucratic organization. These relationships, not personalized in theory, are invariably turned into ties of patronage, which, through the exchange of reciprocal favours, pursue essentially particularistic interests. Whoever holds a public post of any kind will at length instrumentalize the structures and resources of the legislative, executive and judiciary power solely in favour of specific people connected to his network.

For the actors themselves the relationships between patron and client represent the most efficient means to make the State's bureaucratic apparatus more transparent and less rigid. Paradoxically, the clientele system turns out to be a bridging mechanism between State and society that helps to make the citizen's relationship with the public administra- 
tion less troublesome. Consequently, in postsocialist societies in South East Europe or in the Mediterranean area one would rather seek the help of a capable patron than apply directly to the appropriate public office that follows the unpredictable and intrinsically sluggish procedure of the public service.

The clientele system is often interpreted as a legacy of archaic rural-like societies. Consequently, there is a mistaken assumption that such practices, looked upon as obsolete and socially harmful, will disappear thanks to modernization and democratization processes. The far-reaching social changes that have taken place in specific public mistrust societies in Europe have certainly transformed their social fabric. Paradoxically, however, they also triggered the clientele system's adaptation to the new situation. Ironically, we can observe that the classic institution of patronage updated itself, taking on more complex and certainly less archaic forms of organization. In the Italian Mezzogiorno, experts have witnessed the rise and development of a party-political clientele system and/or of a mass clientele system (Graziano, 1974), which ultimately replaced the old clien- tele system of the notables. As opposed to the clientele system of the notables, the new forms of patronage are based on obtaining large quantities of votes in exchange for favours through the shrewd control and instrumentalization of civil society's institutions. The case of Italy, therefore, proves that the institution of patronage is far more flexible and durable than what institutionalist approaches still reaffirm (Putnam, 1993).

All these dyadic and informal personalized relationships and the consequent social practices so widespread in Mediterranean agro-towns should not be considered exclusive to societies perceived as archaic collectivities or ones plagued by social, cultural and moral backwardness (Giordano, 2013). This would be yet another ethnocentric theory of the sociocultural deficit of some societies compared to others, namely Western ones.

An historical-anthropological approach, instead, reveals quite clearly that these relationships and social practices are strictly correlated to a permanent discord between State and society. In Weberian terms we could say that there is a split between legality and legitimacy as shown in the following diagram:

\section{Formal State institutions Informal relationships and social networks}

\section{Legal}

\section{Non-Legitimate}

The roots of this discord between State and society reach deep into a distant history. Yet, history cannot be reduced to a mechanical or automatic sequence of objective facts. Instead, it must be understood as an interpreted past

\section{Partially Illegal or semi-legal}

\section{Legitimate}

activated by the actors themselves in their present to be interpreted (Ricoeur, 1985: Vol. 3, 314). Thus, we reach the question of history as a past that is experienced either in a direct or mediated way and then actualized. This concerns 
what has been defined as the presence or efficacy of history (Ricoeur, 1985: Vol.3, 495). The historical-anthropological view does not deal as much with the sociologically relevant roots of informality, but rather with the social construction of continuity by which informal activities in the minds of members of some societies take on and maintain a specific meaning.

According to the historical-anthropological view, this endurance springs from the tight and permanent interaction between the collective spaces of experience, in the sense of interpreted past, and the horizons of expectation to be considered, instead, as imagined future in the present (Koselleck, 1979: 349 ff.).

Present informality is strictly linked to the dreadful experiences that members of a given society have continuously had with the State both in the recent and in the distant past. Obviously, these negative spaces of experience, which have a marked influence on the actors and on the formation of their horizons of expectation, do not reproduce themselves automatically by tradition. These spaces of experience must be con- stantly confirmed in the present. In accordance with the members' perception of these experiences, the corresponding systems of representations and behavioural models will be strengthened, modified or discarded.

As already mentioned, the reproduction of negative spaces of experience in public mistrust societies goes hand in hand with the constant failing of the State and of civil society's institutions. Yet, such a public inability to carry out one's duties is not only an objective fact that can be observed from the outside, but, far more important, is also shared within and consequently built as such by the citizens themselves. Thus, for the actors affected by the permanent disaster of public powers and civil society's institutions, the persistence, resurgence and expansion of informal behavioural models are simply the outcome of a contextual rational choice. In fact, members of public mistrust societies in Mediterranean agro-towns resort to informality with good reason since nobody is foolish to the point of doing things that serve no purpose or that could be damaging.

\section{CONCLUSIONS: THE ROLE OF SCIENTIFIC DICHOTOMIES AND EVERYDAY DICHOTOMIES}

In this article we have illustrated two types of dichotomies, i.e. those conceived by social sciences as analytical tools and those built by the actors with whom anthropologists and sociologists come into contact and interact also over long periods of time during their fieldwork.

These two types of dichotomies are different yet analogous since the former are ideal-typical conceptualizations not found in reality, whereas the latter are representations of the actors' reality created by the actors themselves that help them find their bearings. The construction of the former implies an abstraction or, better yet, a fiction adopted by the anthropologist and the sociologist. Thus, it is an etic approach, i.e. a vision from the point of view of the experts analysing social phenomena from the outside 
(Pike, 1967). Scientific dichotomies, therefore, cannot be detected via empirical methods because they are abstract conceptualizations, often developed a priori, whose terms are at the opposite extremes of an infinite string of social realities. These two extremes, however, lie outside of empirical evidence. Yet, dichotomies are very useful in comparative analyses, thus also in any attempt to conceive generalizations, however finite and sectoral.

The second type of dichotomy, instead, is an important element of a society's knowledge and social wisdom, which in most cases does not coincide with scientific conceptualizations. These dichotomies may be characterized as an emic approach, i.e. a vision from the point of view of the actors of the society being analysed (Pike 1967). Thus, these social phenomena become apparent during the fieldwork phase.

Dichotomies have a legitimate right to exist in social sciences especially because of the two different dimensions men-

\section{Bibliography}

Bailey, Frederick G. ed. 1971, Gifts and Poison: The Politics of Reputation, Oxford: Blackwell.

Banfield, Edward C. 1958, The Moral Basis of a Backward Society, Glencoe: The Free Press.

Belluardo, Giovanni 1977, Contadini in Sicilia. Problemi psicosociologici del sottosviluppo nell'area iblea. Milano: Franco Angeli Editore

Blok, Anton, Driessen Henk, 1984, Mediterranean Agro-towns as a Form of Cultural Dominance in: Ethnologia Europaea 14: 11-124.

Boissevain, Jeremy, 1974, Friends of Friends: Networks, Manipulators and Coalitions. Oxford: Blackwell

Durkheim, Emile, 1893, De la division du travail social. Etude sur l'organisation des sociétés supérieures. Paris: Félix Alcon. tioned above and despite the often unfair and misleading criticisms, which especially nowadays are being levelled against them also from within social sciences.

On the one hand, being Weberian ideal types, they are useful in the scientific conceptualization and help those who carry out field research make sense of complex social realities. On the other hand, instead, they show the researcher how the actors themselves construct the everyday reality in which they live and act sensibly, thus rationally, precisely because of their collective representations, i.e. based on what may be defined as their local knowledge (Geertz, 1980). Thus, the point is not about finding objective evidence but rather subjective perceptions, albeit of a collective nature. Accordingly, one ought to avoid positivist delusions such as the one found in the renowned controversy, both indirect and across time, between Oscar Lewis and Robert Redfield, regarding the tontos/correctos dichotomy in the Mexican village of Tepotzlan (Redfield, 1930, Lewis, 1970).

Gasparini, Alberto, 1978, Image du travail chez les paysans italiens, in: Sociologia Ruralis, 17, 4: $275-284$.

Geertz, Clifford, 1980, Local Knowledge: Further Essays in interpretive Anthropology, New York: Basic Books.

Giordano, Christian, Hettlage Robert, 1979, Persistenz im Wandel. Das Mobilisierungspotential sizilianischer Genossenschaften. Eine Fallstudie zur Entwicklungsproblematik. Tübingen: J.C.B. Mohr, Paul Siebeck.

Giordano, Christian, 2012, Die politische Kultur in Gesellschaften des öffentlichen Misstrauens: Südosteuropäische und mediterrane Parallelen, in Schüler, Sonja, ed., Politische Kultur in (Südost-) Europa. Charakteristika, Vermittlung, 
Wandel. München, Berlin: Verlag Otto Sagner: 119-136.

Giordano, Christian, 2013, The Social Organization of Informality: The Rationale Underlying Personalized Relationship and Coalitions, in Giordano, Christian, Hayoz, Nicolas eds., Informality in Eastern Europe: Structures, Political Cultures and Social Practices: Bern, Berlin, New York, Oxford: Peter Lang: 27-45.

Giordano, Christian, Greverus, Ina-Maria, eds., 1986, Sizilien - die Menschen, das Land und der Staat, Frankfurt/M.: Notizen, Die Schriftenreihe des Instituts für Kulturanthropologie und Europäische Ethnologie, Universität Frankfurt/M.

Graziano, Luigi, 1974, Clientelismo e mutamento politico. Milano: Franco Angeli Editore.

Koselleck, Reinhard,1979, Vergangene Zukunft. Zur Semantik geschichtlicher Zeiten, Frankfurt/M (Suhrkamp Verlag).

Jenks, Chris, 1998, Core Sociological Dichotomies. New York London: Sage Publishing.

Ledeneva, Alena, V. 1998, Russia's Economy of Favours: Blat, Networking and Informal Favours, Cambridge: Cambridge University Press.

Lewis, Oscar, 1970, Anthropological Essays, New York: Random House.

Li Causi, Luciano, 1979, "Patronage" e clientelismo in una società mediterranea: Lampedusa (18961976), in : Uomo e Cultura, 23-24: 45-76.

Mosca, Gaetano, 1980, Uomini e cose di Sicilia, Palermo: Sellerio Editore

Mühlmann, Wilhelm E., Llaryora Roberto J., 1968, Klientschaft, Klientel und Klientelsystem in einer sizilianischen Agro-Stadt, Tübingen: J.C.B. Mohr, Paul Siebeck Verlag.

Mühlmann, Wilhelm E., Llaryora, Roberto J., 1973, Strummula siciliana. Ehre, Rang und soziale Schichtung in einer sizilianischen Agro-Stadt. Meisenheim/Glan: Anton Hain Verlag.

Ossowski, Stanislaw, 1962, Die Klassenstruktur im sozialen Bewusstsein. Luchterhand: Berlin, Neuwied.

Pike, Kenneth Lee, 1967, Language in Relation to a Unified Theory of Structure of Human Behavior, Mouton: Den Haag.
Pitt-Rivers, Julian, 1977, The Fate of Shechem or the Politics of Sex: Essays in the Anthropology of the Mediterranean, Cambridge: Cambridge University Press.

Pitrè, Giuseppe, 1978, Proverbi siciliani, motti e scongiuri del popolo siciliano. Palermo: Il Vespro.

Putnam, Robert, 1993, Making Democracy Work. Civic Traditions in Modern Italy, Princeton N.J.: Princeton University Press.

Redfield, Robert, 1930, Tepotzlan: A Mexican Village, Chicago: Chicago University Press

Redfield, Robert, 1941, The Folk Culture of Yucatan, Chicago: Chicago University Press.

Ricoeur, Paul, 1985, Temps et récit, Paris: Editions du Seuil.

Schiffauer, Werner, 1983, Die Gewalt der Ehre. Erklärungen zu einem türkisch-deutschen Sexualkonflikt, Frankfurt/M.: Suhrkamp Verlag.

Sciascia, Leonardo, 1976, L'onorevole, Torino: Einaudi.

Tentori, Tullio, 1971, Scritti antropologici, Roma: Editori Riuniti.

Tönnies, Ferdinand, 1912, Gemeinschaft und Gesellschaft. Grundbegriffe der reinen Soziologie, Leipzig: Fues's Verlag

Tylor, Edward B. 1871, Primitive Culture, London: John Murray.

Tullio Altan, Carlo, 1986, La nostra Italia. Arretratezza socioculturale, clientelismo e ribellismo dall' Unità ad oggi, Milano: Feltrinelli.

Weber, Max, 1956, Wirtschaft und Gesellschaft. Grundriss der verstehenden Soziologie. Tübingen: J.C.B. Mohr, Paul Siebeck.

Vuidaskis, Vassilios., 1977, Tradition und sozialer Wandel auf der Insel Kreta, Meisenheim/Glan: Anton Hain Verlag.

Wolf, Eric R., 1966, Kinship, Friendship, and Patron-Client Relations in Complex Societies, in: Banton, Michael, ed. The Social Anthropology of Complex Societies, London: Tavistock Publications, A.S.A Monographs: 1-22.

Zimmermann, Emil, 1982, Emigrationsland Süditalien. Eine kulturanthropologische und sozialpsychologische Analyse, Tübingen: J.C.B. Mohr, Paul Siebeck Verlag. 